\title{
Atlantic Daylight Time
}

National Cancer Institute

\section{Source}

National Cancer Institute. Atlantic Daylight Time. NCI Thesaurus. Code C116256.

Local daylight-savings time, based at the 60th meridian west of the Greenwich

Observatory, established as three hours behind Coordinated Universal T ime. 